\title{
PERAN SERTA PEREMPUAN DALAM PELESTARIAN KESENIAN TAYUB DI DESA PESU KECAMATAN MAOSPATI KABUPATEN MAGETAN
}

\author{
Muhammad Hanif, Yoga Wedhasmara, \\ Aditya Nur Hanafi, Lia Dwi Kuswara *
}

\begin{abstract}
Abstrak
Penelitian ini bertujuan untuk mengetahui peran perempuan dalam pelestarian kesenian Tayub di Desa Pesu Kecamatan Maospati Kabupaten Magetan.

Metode penelitian yang digunakan yakni Metode HermenutikaMendalam Thomson. Sumber data berasal dari sumber lisan, tertulis, dokumen, lembaga sosial dan tradisi. Informan ditentukan dengan snowball sampling dan pengambilan datanya dengan wawancara, observasi, dan pencatatan dokumen. Sedangkan analisis datanya dengan analisis kualitatif model interaktif.

Dari penelitian yang dilaksanakan diperoleh gambaran bahwa perempuan memiliki peran sangat besar dalam melestarikan kesenian Tayub di Pesu. Hal tersebut tercermin dalam perannya sebagai penari (teledek atau sinden) yang terus-menerus mengembangkan kreativitasnya dalam menari, menyanyi, ngadi salira dan ngadi busana, dan sekaligus melaksanakan kaderisasi serta membina apresiasi masyarakat, terutama mencari solusi alternatif untuk mengeliminir citra negatif. Selain itu, tidak sedikit para perempuan di luar komunitas Tayub yang gemar dan nanggap Tayub. Ibu-ibu pejabat juga ikut serta melaksanakan pembinaan-pembinaan sehingga Tayub menjadi lebih menarik dan tetap diminati sampai sekarang.
\end{abstract}

\section{Kata kunci : Perempuan, Pelestarian Tayub}

\section{Pendahuluan}

Perkembangan globalisasi yang ditandai dengan perkembangan tek- nologi informasi komunikasi telah merubah kehidupan manusia di muka bumi ini, baik dari kalangan awam, politisi, intelektual, termasuk seniman dan atau pekerja seni.

\footnotetext{
* Muhammad Hanif Dosen Pendidikan Sejarah IKIP PGRI Madiun; Jl Setiabudi 85 Madiun; email: muhhanieff@yahoo.com.
}

Yoga Wedhasmara, Aditya Nur Hanafi, Lia Dwi Kuswara adalah mahasiswa Pendidikan Sejarah IKIP PGRI Madiun, Jl. Setiabudi 85 Madiun. 
Dunia telah menjadi sistem pertukaran informasi yang besar tanpa mengalami hambatan, dunia tanpa tapal batas. Menurut Kenichi Ohmae sebagaimana dikutip oleh Kanti Walujo (2000:ix-x), tata dunia baru ini disebut the Borderless world. Dengan keterbukaan informasi, seseorang dapat dengan mudah dan cepat mengakses informasi global, termasuk dunia hiburan atau kesenian. Hal tersebut menjadi wahana pertarungan nilai-nilai dari berbagai macam informasi, baik yang bersifat positif maupun negatif.

Dampak dari globalisasi tersebut diantaranya di bidang kesenian tradisional. Secara empirik, mengindikasikan banyak kesenian tradisional semakin terdesak oleh kesenian asing dan budaya populer yang semakin mekar, berkembang dan meluas. Generasi muda sebagai generasi yang diharapkan dapat menjaga kelestariannya ternyata cenderung (trend) tidak menyukai kesenian tradisional. Apabila dipandang masalah tersebut dari sudut pandang pendidikan (enkulturasi dan sosialisasi), maka sangat mengkhawatirkan, terutama soal kesadaran akan jatidiri sebagai bangsa. Dapat dibayangkan, apabila suatu bangsa dimana generasi mudanya tidak lagi mewarisi nilai-nilai budaya bangsanya sendiri, maka sangat mungkin bangsa tersebut akan kehilangan jatidiri dan terperangkap dalam globalisasi. Agar masalah tersebut tidak menjadi kenyataan, maka perlu kiranya adanya upaya nyata untuk mengembangkan kemudian mengenkulturasikan dan mensosialisasikan kepada generasi muda.
Di tengah suasana keprihatinan dan kekhawatiran akan keberlangsungan kesenian tradisional tersebut di atas, ada salah satu komunitas kesenian tradisional yang sampai hari ini masih dapat menunjukkan keberadaannya, yaitu Tayub di Desa Pesu Kecamatan Maospati Kabupaten Magetan. Kesenian Tayub dari desa tersebut sangat terkenal di wilayah Magetan, Madiun, dan sekitarnya. Mereka tidak hanya tampil atau diundang dalam hajatan atau upacara bersih desa, tetapi ada juga beberapa kelompok yang tampil keliling atau "ngamen". Hal ini menimbulkan pertanyaan, mengapa kesenian Tayub dari desa Pesu ini masih dapat bertahan dalam pusaran kehidupan globalisasi dewasa ini? Apalagi jika dikaitan tentang kehidupan penari Tayub yang sering menimbulkan kontroversi. Ben Suharto (1980:70), mengatakan bahwa kehidupan penari Tayub atau para tledek sangat dilekati dengan kehidupan prostitusi. Hal senada juga disampaikan oleh Geertz (1989:401), bahwa Tayuban merupakan kombinasi dari pesta minum-minuman keras dan penarinya juga bisa diajak bersetubuh.

Keberadaan kaum perempuan sebagai pihak penari atau tledek dalam Tayub menjadi salah satu sumbu dari keberlangsungan komunitas tersebut. Apakah mereka mengikuti arus sebagaimana layaknya para tledek pada masa-masa sebelumnya yang lekat dengan kehidupan prostitusi atau sebaliknya mereka mampu beradaptasi dengan perubahan dan menempuh solusi alternatif sehingga dapat meng- 
eliminir pandangan miring masyarakat terhadapnya. Dengan kata lain, bagaimanakah strategi yang dimainkan oleh para perempuan sehingga kesenian Tayub dapat diminati oleh masyarakat sampai dewasa ini ?

Penelitian ini dilaksanakan untuk mendapatkan gambaran yang memadai dan komprehensif tentang peran serta perempuan dalam pelestarian kesenian Tayub di Desa Pesu Kecamatan Maospati Kabupaten Magetan. Hasil penelitian diharapkan dapat bermanfaat bagi:

1. Mahasiswa Program Studi Pendidikan Sejarah FPIPS IKIP PGRI Madiun. Hasil penelitian ini akan sangat berguna dalam pengajaran sejarah kontemporer dan sejarah lokal.

2. Masyarakat, terutama para perempuan, penelitian ini dapat memberikan gambaran tentang gender dan tranformasi nilai, serta dimungkinkan dapat meningkatkan kesadaran sejarah.

3. Pemerintah,

khususnya

Pemerintah Daerah dapat dijadikan bahan untuk mengambil kebijakan dalam pembangunan baik fisik maupun mental, terutama yang berkaitan dengan masalah gender.

\section{Tinjauan Pustaka}

Peran serta perempuan dalam kehidupan sosial budaya dapat dilihat dari sudut pandang transformasi perempuan yang mencakup fungsionalisme dalam feminisme (Fakih, 2003). Selain itu dapat dilihat juga dari sudut pandang gender specifity, yaitu mencakup pola-pola perilaku, ekspresi emosional yang secara sosial dapat dipelajari serta digunakan untuk menilai tingkat keperempuannya dan kepribadian seseorang (Tangdilintin, 1991). Sedangkan Barker (2004) menyatakan bahwa aktivitas ini mengarah pada suatu gerakan untuk mengkonstruksi strategi politik yang digunakan untuk melakukan intervensi ke dalam kehidupan demi mengabdi kepada kepentingan perempuan.

Pola-pola perilaku maupun ekspresi emosional perempuan dapat terungkap melalui tersedianya jejak, baik yang bersifat materiil dan non materiil. Sumber peristiwa yang bersifat materiil diantaranya: prasasti, laporan tertulis, dan sebagainya. Sedangkan yang bersifat non materiil diantaranya: lembaga sosial, etik, tradisi, dan sebagainya. Dengan pengecekan secara kritis sumber sejarah tersebut di atas akan membuka wawasan di dalam melihat peranan perempuan. Hal senada disampaikan Sendratari (1992), bahwa gambaran perempuan dapat digali lewat dokumen dan kesaksian pelaku peristiwa.

Kesenian sebagai bagian dari kebudayaan menurut Talcott Parson (dalam Rahmat K. Dwi Susilo, 2003:4) terkait erat dengan persamaan antara masyarakat dan organisasi hidup, dan sistem kebudayaan mengalami perubahan secara bertahap melalui pen-yesuaian-penyesuaian. Menurut Soerjono Soekanto (1982:261), perubahan sosial pada lembagalembaga kemasyarakatan di dalam suatu masyarakat, yang mempengaruhi sistem sosialnya, termasuk di dalamnya nilai-nilai, sikap-sikap dan pola-pola perilaku diantara 
kelompok-kelompok dalam masyarakat. Lebih lanjut Margaret $M$. Poloma (dalam Rahmat K. Dwi Susilo, 2003:6-7), kebudayaan sebagai sebuah sistem dapat bertahan atau tidak ditinggalkan pendukungnya apabila:

1. Adaptasi, yaitu melindungi dan mendistribusikan alat-alat ber-tahan dari lingkungan atau menyesuaikan tuntutan-tuntutan dari lingkungannya.

2. Pencapaian tujuan, yaitu menentukan, mengatur, dan memfasilitasi pencapaian tujuan dari sistem sosial.

3. Integrasi, yaitu hubunganhubungan sosial yang melindungi secara kooperatif dan ter-koordinasi dalam sistem.

4. Latensi, yaitu terdapat pemeliharaan pola-pola didalamnya motivasi dari perilaku yang diingini.

Hal senada disampaikan oleh Sri Rochana Widyastutiningrum (2007: 25), bahwa perkembangan kesenian Tayub dapat merujuk pada teori sejarah Arnold Toynbee tentang perubahan sosial. Menurut Toynbee, perubahan sosial yang signifikan (baik bentuk-bentuk pertumbuhan maupun kemunduran) disebabkan oleh tanggapan masyarakat terhadap tantangan yang mengakibatkan terjadinya perubahan sosial. Perubahan tersebut melalui saluran-saluran sebagai prosesnya. Umumnya saluran-saluran tersebut meliputi lembaga-lembaga kemasyarakatan dalam bidang politik, ekonomi, pendidikan, rekreasi, dan sebagainya. Saluran ini berfungsi agar sesuatu itu dikenal, diterima, diakui, serta dipergunakan oleh khalayak ramai, atau dengan singkat mengalami proses pelembagaan (Soerjono Soekanto, 1982:292).

Gerak perubahan tersebut di atas bergerak meninggalkan faktor yang diubah. Akan tetapi, setelah meninggalkan faktor itu, mungkin perubahan bergerak kepada suatu bentuk yang sama sekali baru, atau mungkin pula bergerak ke arah suatu bentuk yang sudah ada di dalam waktu yang lampau, dan mungkin juga penyesuaian terhadap perubahan dan kemampuan mencari solusi tindakan alternatif sehingga dapat bertahan atau lestari.

\section{Metode Penelitian}

Penelitian ini menggunakan Metode Hermenutika-Mendalam Thomson (Thomson, 2004). Dipilihnya metode karena penelitian tidak hanya serentetan objek dan peristiwa yang akan diteliti dan dijelaskan, tetapi juga domain subjek yang dirancang sebagai subjek yang dalam rutinitas kehidupan sehariharinya, secara konstan berada dalam pemahaman dirinya dan orang lain dalam menghasilkan tindakan dan ekspresi yang bermakna serta dalam menafsirkan tindakan dan ekspresi yang bermakna yang dilakukan oleh orang lain.

1. Sumber Data Penelitian

Sumber data yang digunakan berupa sumber materiil dan non materiil. Sumber materiil diantaranya: sumber lisan/kesaksi-am, laporan tertulis, dan dokumen. Sedangkan yang non materiil 
diantaranya: lembaga sosial dan tradisi.

\section{Informan}

Mengingat informan belum diketahui secara pasti, maka penentuan respondennya peneliti menggunakan teknik snowball sampling.

\section{Pengambilan Data}

Pengambilan data menggunakan teknik wawancara, observasi, dan pencatatan dokumen.

4. Analisis Data

Dalam menganalisa data, peneliti menggunakan analisis kualititatif model interaktif (Sutopo, 1990) sebagaimana bagan dibawah ini.

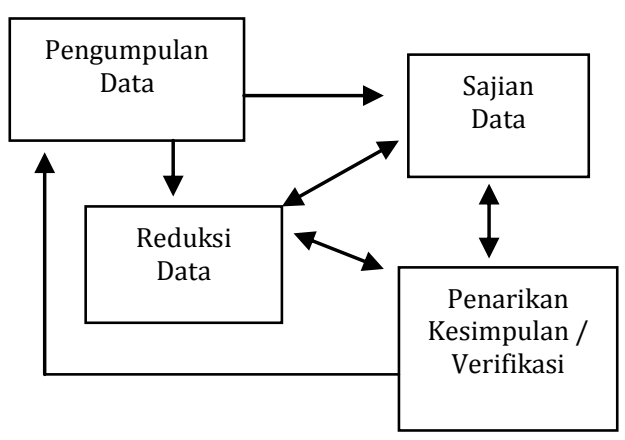

\section{Bagan 1 : Model Analisis Interaktif}

Penelitian ini dilakukan di Desa Pesu Kecamatan Maospati Kabupaten Magetan. Sedangkan waktu penelitian mulai bulan Februari sampai Mei 2011. Instrumen yang digunakan antara lain: pedoman wawancara, laptop, LCD, camera.

\section{Hasil Penelitian}

\section{Pengertian Kesenian Tayub}

Banyak ragam pendapat yang berkembang di masyarakat tentang pengertian Tayub. Menurut para seniman Tayub (Bari, Bambang Sujono, Edi Sumitro,Warsi) Desa Pesu Kecamatan Maospati Kabupaten Magetan, kesenian Tayub me-rupakan sebuah seni yang biasa disebut juga gambyong yang dalam masyarakat diartikan sebagai sebuah seni untuk men-cipkatan kondisi yang tentram atau guyub.

Pendapat tersebut di atas sejalan dengan pengertian dari berbagai sumber lainnya. Menurut tradisi lisan, Tayub dikeratabasakan atau dijarwodosaken menjadi sebuah kalimat Jawa yaitu ditata cikben guyub. Maksudnya, tarian diatur secara baik agar terwujud menjadi kerukunan orang. Sedangkan menurut ahli bahasa (dalam Rachmad K. Dwi Susilo, 2003:7), Tayub dimaknai dengan kasukan jejogedan nganggo dijogedi ing tledek. Maksudnya, bersukaria menari dengan diiringi bersama tledek, yaitu penari yang menari pada acara Tayuban. Selain itu disampaikan juga bahwa Tayub ditemukan dalam Kakawin Bharata Yudha karya Mpu Sedah dan Mpu Panuluh pada zaman Jayabaya di Kediri. Dalam kitab itu tertulis kata sapannddawanayub yang mempunyai arti "mereka (pandhawa) menarinari". Hal ini berarti kata Tayub bermakna "tari" atau "menari-nari" (Suripan Sadi Hutomo, 1996:93).

Dari beberapa pendapat dan sumber di atas dapat ditegaskan 
bahwa Tayub dipadankan artinya dengan tledek dan gambyong, yaitu sebuah pertunjukan hiburan yang selalu menghadirkan penari wanita (tledek) dan mengajak penikmat (lakilaki) untuk menari bersama.

Susunan pertunjukan Tayub biasa diatur dengan urutan tertentu, yaitu: 1) sajian gending-gendhing; 2) gambyongan (tari gambyong); 3) pambagyaharja (ucapan selamat datang); dan 4) Tayuban yang terdiri dari: panembrama atau bawa (penghormatan bagi yang punya hajat), dan ngibing. Sedangkan para pelaku seniman Tayub terdiri dari teledek, pengarih (pengatur jalannya pertunjukan Tayub), dan pengrawit atau panjak.

\section{Perkembangan Kesenian Tayub di Desa Pesu Kecamatan Maospati Kabupaten Magetan}

Tayub pada mulanya adalah kesenian yang berasal dari kraton yang tumbuh dan pelihara langsung oleh raja. Tetapi seiring dengan perkembangan zaman, terutama setelah kemasukan budaya asing yang tidak cocok dengan budaya keraton, yaitu ciu (minuman keras), colek, dan cium, maka Tayub dinilai hilang kesakralannya dan tidak lagi dipertontonkan di dalam keraton kemudian menjadi kesenian rakyat. Tayub sebagai kesenian rakyat tumbuh subur di banyak tempat, termasuk di Desa Pesu.

Awal mula timbulnya kesenian Tayub di Desa Pesu belum dapat diketahui secara pasti. Dalam dinamikanya, Tayub diwarnai kontradiksi-kontradiksi nilai-nilai yang berkembang di masyarakat. Sebagian masyarakat mengkonotasikan Tayub sebagai kesenian negatif yang lekat dengan portitusi dan pelecehan seksual. Namun di lain pihak, kesenian Tayub mengandung magis yang berkaitan dengan kepercayaan ritual yang dimiliki masyarakat terhadap makhluk gaib. Tayub dilakukan sebagai upaya untuk menghindari diri dari makhuk gaib "marah" dengan menebarkan wabah (pagebluk). Tayub dilaksanakan sebagai ritualisme agar masyarakat mendapat keselamatan. Upacaraupacaranya diantaranya sedekah bumi (bersih desa), perkawinan, membayar nazar (kaul), dan sebagainya. Hal inilah yang mendasari masyarakat Desa Pesu sampai sekarang masih melestarikannya.

Hingga sekarang ada satu kelompok yang masih eksis dalam menjalankan perannya sebagai para seniman Tayub. Kelompok tersebut bernama "MARSUDI LARAS" dengan ketua kelompoknya Bari (60 Tahun). Sudah hampir empat puluh tahun Bari menjadi seniman Tayub, dan itulah yang menjadikan Tayub seperti sebuah bagian dari kehidupannya.

Sebagai bagian dari sistem kebudayaan, tradisi Tayub tidak pernah berhenti dalam perkembangannya. Seiring dengan perkembangan zaman, Tayub di Desa Pesu memiliki kemampuan untuk melakukan penyesuaian diri. Selain karena fungsi magis sebagaimana dijelaskan di atas, Tayub dikembangkan sebagai sebuah tontonan atau acara-acara hiburan. Acara ini diselenggarakan sebagai ungkapan rasa bahagia dan bersyukur. Tayub sebagai hiburan yang ditonjolkan 
adalah kenikmatan berperan serta penari laki-laki (pengibing) dengan tledek. Dalam pertunjukkan Tayub biasanya ada tiga teledek atau lebih. Mereka mengenakan busana yang cukup merangsang bagi laki-laki. Selembar kain panjang membelit dengan ketat tubuh bagian bawah. Dadanya mengenakan kemben (kain ciut panjang yang membungkus dengan kencang sebagian dari dadanya, sehingga bagian yang paling merangsang sedikit menyembul ke atas. Kepala yang bersanggul dihiasi dengan bunga, selembar selendang dengan warna panas yang tergantung di pundak kanan merupakan properti yang sangat penting untuk "menggait" laki-laki pengibing. Apabila melangkah, lipatan kain (wiron) yang berada di depan tubuh sesekali diangkat, sehingga betis si teledek akan sedikit kelihatan.

Seperti dengan pertujukan pada umumnya dalam pementasan Tayub juga dipandu oleh pembawa acara (Panatacara) yang memandu jalannya pementasan. Adapun mengenahi biaya pementasan (ditanggap) sekitar tiga juta hingga lima juta rupiah. Perkiraan tersebut karena memang terdapat tawar menawar sebelum terjadi pementasan. Adapun mengenahi pembagian komisi diatur sepenuhnya oleh ketua kelompok, dalam sekali pementasan biasanya ada 14 pemain yang terbagi dari penabuh alat musik, para sinden atau penyanyi, kemudian penari atau tledek. Dari semua pemain, komisi dibagi secara merata antar pemain sekitar seratus ribu hingga dua ratus ribu, tetapi untuk ketua kelompok tetap mendapat bagian yang lebih banyak karena sebagai koordinator sekaligus penanggung jawab pementasan tersebut.

Pertunjukkan Tayub kian semarak apabila tledek dapat tampil ramah, genit, trampil dan menggemaskan, serta dengan minumminuman keras. Dalam konteks ini, Tayub mengalami pergeseran fungsi. Maksudnya tidak lagi dihubungkan dengan hal-hal yang gaib tetapi sesuatu yang mendekati maksiat, seperti senggol-senggolan, uang susu (memasukan uang atau tips ke kemben tledek), bahkan bisa "diapaapakan" oleh laki-laki, dan lainlainnya. Sehingga tledek dan Tayub citranya negatif dan mengundang kritikan dari para tokoh-tokoh agama dan pemuka masyarakat lainnya.

Menghadapi kritikan dan label negatif trersebut para seniman Tayub desa Pesu tidak membutakan diri atau menulikan diri. Menurut Bari sebagai ketua kelompok sekaligus seniman, mereka sudah melakukan adapatsi dalam pementasan Tayub. Kalau dulu ada istilah uang susu, sekarang diganti dengan uang gong, yang artinya bahwa pengibing diharuskan untuk memberikan uang dalam mengibing dengan memasukkannya ke dalam gong. Ini dimaksutkan untuk tetap menjaga nama baik dari Tayub itu sendiri, bahwa Tayub merupakan sebuah karya seni yang unik, bukannya seni yang cenderung maksiat.

Mereka menyadarinya, akan tetapi terkadang dalam penyelenggaraannya ada tuntutan dari yang punya hajatan. Walaupun begitu mereka mampu menyesuaikan diri dengan nilai-nilai agama dan moral 
yang dipedomani masyarakat pada umumnya. Diantaranya uang susu diganti dengan uang gong atau uang piring (tip dari pengibing tidak dimasukan ke kemben, tetapi diletakkan di piring atau gong yang dibalik yang telah disediakan), pakaiannya yang merangsang mulai dieliminir. Selain itu, mereka juga adaptif dengan perkembangan kesenian modern, diantaranya lagulagu yang dibawakan yang biasanya menggunakan tembang-tembang Jawa diselipi dengan beberapa lagulagu yang sekarang sedang populer, dan humornya dikontekstualisasikan dengan berita-berita yang aktual. Hal tersebut tentunya dilakukan dengan dasar agar kesenian ini dapat tetap eksis dan dapat diterima oleh umum, tandas Pak Bari selaku Ketua Kelompok dari Marsudi Laras.

\section{Peran Perempuan dalam Pelestarian Kesenian Tayub di Desa Pesu}

Dalam perkembangan zaman seperti sekarang ini banyak tantangan yang dihadapi oleh para seniman Tayub. Selain itu citra negatif yang terlanjur melekat dalam pandangan kebanyakan orang, Tayub juga dihadapkan dengan kesenian-kesenian modern yang gencar menyerbu wilayah ini sehingga mengancam keberlangsungannya. Menghadapi masalah ini, tampak Tayub dapat bertahan. Untuk mengungkap peran yang dimainkan oleh perempuan dalam pelestarian Tayub dapat didekati secara internal dan eksternal. Secara internal, menunjuk pada perempuan pelaku kesenian Tayub, sedangkan eksternal menunjuk pada kaum perempuan di luar lingkup komunitas kesenian Tayub.

a. Kelompok Internal Tayub

Dalam kelompok Tayub, perempuan mempunyai peran yang sangat penting, yaitu sebagai pesinden atau tledek dan ini menjadi pusat perhatian para penonton. Untuk itu, tledek harus memiliki kemampuan menari, menyanyi, dan berbagai kemampuan lain yang mendukung selama pertunjukkan. Menari juga harus sumeh, kenes, luwes, dan menarik. Selain itu, juga dituntut memiliki modal dalam penguasaan gendhing, tari, rias, dan busana. Selain itu juga membunyai bentuk tubuh yang ideal dan wajah cantik.

Para seniwati Tayub Desa Pesu menyadari bahwa kehadiran penari sangat menentukan keberhasilan setiap pertunjukkan Tayub termasuk keberlangsungan kesenian tersebut, maka mereka melaksanakan berbagai upaya yaitu :

1) Meningkatkan kreativitas dalam menari, menyanyi, berias dan berbusana (ngadi busana)

Dalam menari, para tledek memperluas volume gerak, perubahan dinamika gerak, dan kualitasnya. Mereka berusaha lebih memahami tubuh yang digunakan untuk sebagai sarana menyampaikan pesan.

Dalam gendhing atau nembang, mereka memperkaya perbendaharaan dan memperdalam penguasaan teknik dan penjiwaaan. Selain itu lagu-lagu pop atau dangdut yang akrab ditelinga masyarakat dikemas dalam nada dan irama gending Tayub. Hal ini sebagaimana yang disampaikan oleh Ista selaku sinden. Dengan 
adanya improvisasi tersebut menjadikan Tayub sebagai kesenian tradisioanal yang dapat diterima ditengah perkembangan seni-seni modern seperti sekarang ini.

2) Mengadakan regenerasi

Para seniwati mentransfer pengetahuan tentang nilai-nilai yang terkandung dalam kesenian Tayub, perlunya dilestarikan, dan memotivasi untuk melestarikannya. Selain itu, mereka juga melakukan pembelajaran tentang menari dan menyanyi dengan mengikutkan calon teledek dalam kegiatan pentas para senior. Contohnya yang dilakukan Bari (60 Tahun) dan istrinya warsi (52 tahun) selaku senior di bidang seni Tayub. Mereka biasanya meluangkan waktunya setiap dua minggu sekali yang biasanya pada malam minggu yaitu digunakan untuk membimbing dan melatih para yunior yang berapresiasi dalam mengembangkan dan melestarikan kesenian Tayub tersebut. Menurut Edi (46 Tahun) salah satu pemain yunior Tayub mengatakan bahwa bermain Tayub itu menyenangkan. Selain senang memainkan Tayub, Edi juga bangga karena bisa turut serta menjaga kelestarian budaya tersebut. b. Kelompok Eksternal Tayub

Masyarakat Desa Pesu termasuk masyarakat agraris, sehingga berbagai kegiatan ritual yang berhubungan dengan kesuburan tanah dan keinginan untuk mendapat berkah yang melimpah mendorong mereka melaksanakan ritual dengan pertunjukkan Tayub (upacara sedekah bumi dan upacara bersih desa). Hampir di setiap desa di wilayah Pesu dan sekitarnya mengadakan upacara bersih desa dengan menggelar Tayuban setiap tahunnya. Selain itu, tidak sedikit orang yang punya hajatan perkawinan dengan nanggap Tayub atau Tayuban. Pada saat Tayuban tidak sedikit kaum perempuan yang melihat dan terhibur. Upacara dan banyaknya tanggapan ikut memberi andil lestarinya kesenian Tayub.

Upacara pelestarian kesenian Tayub ini juga mendapatkan perhatian dari pemerintah. Pemerintah Kabupaten Magetan tidak sekadar mendukung, tetapi juga dengan usaha pembinaan. Melalui ibu-ibu PKK dalam pembinaan kesenian Tayub semakin baik, ada beberapa hal yang dilakukan perubahan antara lain mengenahi pengenaan perlengkapan yang lebih baik. Adapun mengenahi wujud kepedulian pemerintah daerah dengan bantuan peralatan tayup agar bisa digunakan untuk latihan dan pementasan. Selain itu, pemerintah juga berupaya untuk membantu meningkatkan kemandirian dalam bidang ekonomi, salah satunya dengan bantuan pertanian agar kehidupan para seniman Tayub dan warga sekitar Desa Pesu bisa menjadi lebih baik.

Hasil pembinaan itu mampu mengubah urutan pertunjukan dan elemen-elemennya seperti rias, busana, meniadakan minumminuman keras, sehingga Tayub lebih menarik dan diterima sebagian besar anggota masyarakat. 


\section{Pembahasan}

Cikal bakal kesenian Tayub di Pesu sampai sekarang belum diketahui secara pasti, namun demikian apabila melihat perkembangan Tayub secara umum dimungkinkan mulai berkembang antara abad X-XV. Hal ini didasarkan pada pendapat Sri Rochana Widyastutiningrum (2007:2) yang mengatakan bahwa pertunjukan Tayub berkembang pada masa kerajaan Kediri dan menyebar ke Demak pada abad ke-15. Pengaruh kerajaan Kediri sampai juga di wilayah Maospati. Hal ini yang ditandai dengan Prasasti Sendang Kamal yang berangka tahun 991 perintah Prabhu Shri Maharaja Teguh Dharmawangsa

Anantawikramatunggadewa yang memerintah Kerajaan Medang dan pada abad XV wilayah ini merupakan bagian dari Kesultanan Demak. Apabila dilihat fungsi Tayub sebagai ritual kesuburan sangat mungkin juga berkembang pada masa Majapahit karena di dekat Pesu tepatnya di Klagenserut ditemukan patung Dewi Sri sebagai lambang kesuburan dan pemberi berkah di sektor pertanian. Seni tayub mengalami perkembangan pada masa Kesultanan Mataram (abad ke-18) (Muhammad Hanif, 2010:49).

Kreativitas para seniwati (perempuan) dalam ber-Tayuban didorong adanya kesadaran perlunya proses regenerasi dan menjalani perkembangan pada kesultanan Mataram (abad 18), dan adaptasi terhadap tuntutan zaman serta perhatian para perempuan di luar komunitas Tayub membuat Tayub di Desa Pesu dapat lestari sampai sekarang. Hal ini menunjukkan bahwa mati hidupnya suatu kebudayaan (kesenian salah satu unsurnya) sangat tergantung pada pendukung kebudayaan itu sendiri.

\section{Kesimpulan dan Saran}

\section{Kesimpulan}

Peran perempuan dalam melestarikan kesenian Tayub di Pesu sangat besar. Hal tersebut tercermin dalam perannya sebagai penari (teledek atau sinden) yang terusmenerus mengembangkan kreativitasnya dalam menari, menyanyi, ngadi salira dan ngadi busana, dan sekaligus melaksanakan kaderisasi serta membina apresiasi masyarakat, terutama mencari solusi alternatif untuk mengeliminir pandangan negatif masyarakat terhadap Tayub.

Selain perempuan yang berada dalam komunitas Tayub, tidak sedikit kaum perempuan yang menggemarinya dengan melihat dan nanggap Tayub. Ibu-ibu pegawai pemerintah juga ikut serta melaksanakan pembinaan-pembinaan terhadap komunitas Tayub sehingga Tayub menjadi lebih menarik tetap diminati sampai sekarang.

\section{Saran}

a. Kepada para seniman Tayub agar senantiasa meningkatkan kreativitasnya dan tetap memperhatikan nilainilai moral yang dipedomani masyarakat sekitarnya sehingga Tayub tidak ketinggalan zaman dan tidak diminati. 
b. Kepada generasi muda, agar dapat mempelajari dan mengambil nilainilai Tayub dan ikut serta melestarikan, tidak perlu malu terlibat di dalamnya, serta menyebarluaskan dengan memanfaatkan teknologi informasi.

c. Kepada pemerintah desa, kabupaten dan provinsi agar selalu memberi perhatian dan pem-binaan, serta memfasilitasi upaya-upaya pengembangan kesenian Tayub. 


\section{Daftar Pustaka}

Barker, Chrish. 2004. Cultural Studies. Yogyakarta: Kreasi Wacana.

Ben, Suharto. 1980. Tayub: Pertunjukan dan Pitus Kesuburan. Bandung: Masyarakat Seni Pertunjukan Indonesia.

Christina dkk. 2001. Jaman Daulat Rakyat Dari Otonomi Daerah Ke Demokratisasi. Yogyakarta: Lapera Pustaka Utama

Christina, M. 2001. Perempuan dalam Otonomi Daerah dan Perempuan Dalam Pusaran Demokrasi. Bantul: IP4 Laperra Indonesia.

Fakih, Mansour. 2003. Analisis Gender Dan Tranformasi Sosial. Yogyakarta: Pustaka Pelajar. 2003. Partisipasi Politik Perempuan Minang Dalam Sistem Masyarakat Matrilineal. Padang: LP2EM

Geertz, Clifford. 1989. Abangan, Santri, Priyayi dalam Masyarakat Jawa. Terjemahan Aswab Mahasin. Jakarta: Pustaka Jaya

Kanti Waluyo. 2000. Dunia Wayang Nilai Estetis, Solidaritas Dan Ajaran Hidup. Yogyakarta: Pustaka Pelajar.

Muhammad Hanif. 2010. Pembabakan Sejarah Kabupaten Madiun dan Peme-taan Peninggalan Sejarahnya sebagai Bahan Ajar IPS SD. Madiun : PS Sejarah (laporan hasil penelitian).

Rahmad K. Dwi Susilo. 2003. Pergeseran Fungsi Tayub
Dalam Masyarakat Blora dalam Agama Tradisional Potret Kearifan Hidup Masyarakat Samin dan Tengger. Yogyakarta: UMM Press dan LKiS.

Sendratari, Luh Putu. 1992. Wanita Dalam Dimensi Sejarah Implikasi dalam Pendidikan Sejarah dalam Aneka Widya. Singaraja: FKIP Universitas Udayana.

Sri Rochana Widyastutieningrum. 2007. Tayub di Blora Jawa Tengah. Surakarta: Pascasarja ISI Surakarta dengan ISI Press. Soerjono Soekanto. 1982. Sosiologi Suatu Pengantar. Jakarta: PT. Raya Grafindo

Sutopo. 1990. Kritik Seni Sebagai Pendekatan Kualitatif. Surakarta: UNS

Suhartono. 2001. Politik Lokal, Parlemen Desa: Dari Awal kemerdekaan Sampai Dengan Jaman Otonomi Daerah. Yogyakarta: Lapera Pustaka Utama.

Tangdilintin, Paulus. 1991. Peranan Wanita Konsep Kunci Yang Masih Perlu Definisi, dalam Antarwidya Nomor 3 Tahun 1 Jakarta: PAU-IS-UI.

Thompson, John B. 2004. Kritik Ideologi Global Teori Sosial Kritis Tentang Relasi Ideologi Dan Komunikasi Massa. Yogyakarta: IRCiSoD. 